\title{
Bangabandhu Sheikh Mujibur Rahman in the Formation of War-torn Bangladesh
}

\author{
Md. Hasan Tawhid ${ }^{1}$ and Md. Rajaul Karim ${ }^{2}$ \\ ${ }^{1}$ Department of MIS, Khwaja Yunus Ali University, Enayetpur, Sirajganj, Bangladesh; ${ }^{2}$ Bangladesh Studies, Khwaja Yunus \\ Ali University, Enayetpur, Sirajganj, Bangladesh. \\ *Correspondence: mdrezaulkarim801@gmail.com (Dr. Md. Rajaul Karim, Senior Lecturer, Bangladesh Studies, Khwaja \\ Yunus Ali University, Enayetpur, Sirajganj, Bangladesh).
}

\begin{abstract}
The main consciousness of the Pakistan movement was the economy. At least in the case of Bengal, it was truer. At one stage the religion movement became stronger when it was associated with religion. In the context of which Pakistan was established with the sacrifice and support of the people of Bengal. But the continued absence of democracy and constitutional rule in Pakistan complicates the situation. The people of Bengal joined the movement under the leadership of Bangabandhu to change the situation. Forced to do so, the Pakistani authorities held the first general election in 1970. In the election, the popular political party of Bengalis, Awami League, won a single majority. Even after the Awami League gained a single majority, the Pakistani authorities did not hand over-power. As a result, Bangabandhu declared the independence of Bangladesh. Bangladesh gained independence after a long nine-month war. At the end of the war, Bangabandhu took over the responsibility of the head of state and devoted himself to the formation of the country. In the present article, Bangabandhu's various steps in the formation of war-torn Bangladesh have been explored.
\end{abstract}

Keywords: War-torn Bangladesh, Bengali liberation movement, Awami League, and Mujibnagar government.

\section{INTRODUCTION:}

Only the traces of oppression and exploitation can be remarked in the historical analysis of successive events of Bangladesh liberation movement. Bangladesh once a poor country in sense of economy, administration and power had to walk a long hostile road to come out of the long-lasting bacon of oppression. After the partition of 1947 east Bengal turned into East Pakistan as a state of newly bore Pakistan. But being recently freed from colonialism Pakistani ruler could not come out from their imperialistic mindset. Consequently, freedom of Pakistan from British rule just turned East Pakistan into a new colony of West Pakistan. Bengali nation was formed as an ethnic group in the subcontinent through a historical evolution of thousands of years before the state Bangladesh formed. Bengali nation was a unique UniversePG I www.universepg.com national entity in a sense of the own language, culture, religious festive, life style, hospitality, secularism and heartiness. To create a new blend of nationalism destroying the Bengali ethnicity was the fundamental motive of the Pakistani ruling class. To achieve their objective systematically they interfered in people's language, religious harmony, economy and political rights of this region. That's why the leader of the Bengali nation Bangabandhu Sheikh Mujibur Rahman (Safar 1970; Moudud, 1990) opposed the proposal of renaming East Bengal to East Pakistan. On $25^{\text {th }}$ August 1955 while speaking in a national assembly. Bangabandhu said "The word Bengal has a tradition of its own." His robust contribution was cited in every scenery of our Liberation movement. The people of East Pakistan fought for 23 years to achieve their demand 
from Pakistani ruling class through different form of movement and negotiation, but failed. Finding no solution, the people of East Pakistan started to prepare for the armed movement responding to the call of Bangabandhu Sheikh Mujibur Rahman through his historical speech on $7^{\text {th }}$ March, 1971 (Rahman, 1995; Politics' Newsweek, 5 April, 1971). On 26 ${ }^{\text {th }}$ March, 1971 through the declaration of independence the Bengali people jumped into direct war against the west Pakistani ruling class. After a 9-month long liberation war the people of East Pakistan clinched their muchawaited victory from West Pakistan. On $16^{\text {th }}$ December, 1971 through the surrender of Pakistani military forces a new in-dependent country named "Bangladesh" was born in the global map of history. But the people of this country had to pay a high price for their independence. The liberation war was conducted under the direction of Mujibnagar Sarker - an expatriate government that was formed by Tajuddin Ahmed on $10^{\text {th }}$ April, 1971 (Rashid, Dr. Harun-or, 2001). Bangabandhu was detained by the Pakistani military forces on $25^{\text {th }}$ March, 1971; just after the declaration of Independence (Maniruzzaman, Talukder, 1975). After a nine-month long detention in Pakistan jail Bangabandhu returned home through London and Delhi on $10^{\text {th }}$ January 1972 as the president of Mujibnagar Government. As the first president of Independent Bangladesh Bangabandhu initiated parliamentary system of government through an interim constitutional decree. To form a parliamentary government Bangabandhu took his oath as the first President of the country from chief justice Abu Sayeed on $12^{\text {th }}$ January and took charge as the prime minister of the country resigning his Presidency. Through this event the journey of Awami League started under the leadership of Bangabandhu which ended on $15^{\text {th }}$ August, 1975 through a tragic event of killing Bangabandhu along with all of his family members. The tenure of Bangabandhu government lasted only for 3 years and 7 months; a very small period of time to plan for the formation of a war-torn country (Bhatanagar, Yatinda, 1971). Though such a short period of governance is not enough to build a Bangladesh Bangabandhu dreamt of, but the experts still think the initiatives and actions of Bangabandhu government are still considered to be a guiding roadmap to the formation of a developed state. To evaluate the future-oriented steps of Bangabandhu government UniversePG I www.universepg.com in the trans-formation of War-torn Bangladesh is the main objective of this study (Maniruzzaman, Talukder, 1982).

\section{Research gap}

None of the published books and articles on Bangabandhu's contribution to the formation of war-torn Bangladesh found a place for research and analysis. In other words, in most of the published books and articles on the formation of Bangladesh, some issues have been discussed sporadically from a general point of view. Therefore, we have written this article realizing the need to study the role of Bangabandhu in the formation of war-torn Bangladesh.

\section{Research methods and data collection}

Basically, we collected data from both primary and secondary sources. We have studied newspapers, periodicals, published books, research articles. Information has also been collected from various political programs broadcast on Bangladesh Radio, BTV and BBC. We have collected information by participating in various political meetings and conferences. To gather information on Bangabandhu's role in building a war-torn Bangladesh, we interviewed politicians from different parties and some important ministers in Bangabandhu's cabinet. In addition, we have studied the necessary official documents from the National Museum of Bangladesh.

\section{Post war situation of the country}

Prior to Independence this region of Bengal had a long history of deprivation and oppression. During the colonial period the development activities were mostly performed centering the region West Bengal; the present Kolkata. In 1905 during Bango Vango (Bengal partition) although the eastern part of Bengal had started to see some mentionable initiative of development but was halted under the incessant protest from part of the West Bengal's political leaders. Consequently, the flow of development of this region came to a halt in 1911 through the event of Bangovango Rod (dismissal of Bengal partition). But unfortunately, this small portion of infra-structural development of this region attained through a long period of time came into havoc after the 9 months long Liberation war of 1971 (Jones, 1972). Bangabandhu undertook the responsebility of forming a newly born country when it was nothing more than a land of disaster and havoc devas- 
tated by the Pakistani military forces. Neither had it had any administrative structure nor any form of economic potential at that time. The Pakistani forces burned out the villages of this region indiscriminately. They also burned out the localities alongside the road, culverts, bridge, rail, and waterways. The educational Institutions of the country, Trade and Commerce industry everything was closed at that moment. The power of police and security forces necessary for the law-andorder situation of a country was very limited in the country. Transportation and communication system was broken down due to the devastating condition of the bridge, road and culverts. National monetary fund was almost empty due to the closure of the banks. The Pakistani military forces also ran their devastation on the government warehouses of food grain, seeds, fertilizer, pesticides and medicine; which intensified the food crisis in this region prevailing in the war period (Manzur, 1979). Pakistani military forces burnt about 43 lac houses, 3000 office buildings, 18000 primary schools, 6000 High Schools, 900 college buildings, and 19000 villages Bazaar in the country, which completely ruin the educational activities and normal lifestyle of people of this country. They also destroyed the electric power stations across the country. There was no stock of electric cable and pole in the warehouses when Bangabandhu took power. Shortage of well-skilled labor prevailed in the banking sector; since $60 \%$ of the bank workers were non-Bengali. Acute shortage of skilled workers in every sector like post, rail and industry created a new obstacle in the formation of the war-torn country since most of the workers were from West Pakistan (Hassan, 1994). More over skill professsionals like doctors, engineers, agriculturist necessary for the reformation of a country were not available. Besides, the nonexistence of constitution and law, noncooperation from part of the foreign countries through this war-torn country into the ocean of uncertainty. Henry Kissinger the then US secretary to state termed Bangladesh as a bottomless basket. Mr. Kissinger hurleda implied challenge regarding the success ability of reformation of the country saying "Let's see where Mr. Mujib takes you in the name of socialism." Doubting the development potential of this country renowned economist Jast Fay land and Parkinson in their writings "Bangladesh: The Test Case of Development"- predicted that the situation of this country will be terribly bad. According to their opinion if Bangladesh can succeed in their economic development, then any country of the world can do this (Bhatanagar, 1971).

\section{Bangabandhu in the formation of War-torn Bangla- desh}

Bangabandhu was a man of optimism and wise personality. He was committed to present the nation a country free of hunger, oppression, discrimination and a country of equity and secularism. He wanted to build a country where the rule of justice, fundamental human rights, and political, economic and social justice will be ensured for each of the citizen (Salik, Siddiq, 1978). On $26^{\text {th }}$ March 1972 , in the occasion of country's $1^{\text {st }}$ Independence Day celebration Bangabandhu in a television speech said "My government believes in internal social revolution. It's not merely an undemocratic goal. My government and party are committed to establish scientific socialist economy in the country. The older social system needs to be uprooted to compose a foundation of a new system. We will form an exploitation free society" (Rahman, 2005). Bangabandhu's government was very much conscious regarding their duty while undertaking the power. It was very much clear to Bangabandhu which work to be conducted on priority basis to reform a war-torn country in the earliest time. His long cherished political experience like 21 points claim in 1954, historical 6point movement, 11-point electoral manifesto of 70's general election etc. guided him to be an effective policymaker in administration (Mamoon et al., 2019).

\section{Bangabandhu's Governance and Constitution For- mulation:}

On $12^{\text {th }}$ January, 1972 Bangabandhu takes power as the prime minister of the country and formed a 12-member cabinet. In the first cabinet meeting of Bangabandhu some important fundamental decisions were taken like:

1) National flag of "Bangladesh was modified and finalized.

2) Tagore's song "Aamar Sonar Bangla Aami Tomai valobashi" - were determined as the nationnal anthem of the country.

3) Nazrul Islam's "Chol Chol Chol, Urdho Gogone Baaje Madol" was selected as the national war song of the country (Huq, Obaidul, 1996). 
The constitution of independent Bangladesh was a true reflection of Bangabandhu's philosophy of development and politics which were formulated just within 10 months of Bangabandhu's home coming day (Maniruzzaman, 1975). In section 2 of 1972's constitution it is said that "Nationalism, socialism, democracy and secularism will be the fundamental principles of our constitution." The reality of desired Bangladesh that Bangabandhu cited in his $7^{\text {th }}$ March speech was truly reflected in 72's constitution. Bangabandhu in his speech said "we want human rights in our country, we want freedom, independence, discrimination free society, we want eradication of sectarianism and justice for humanity (Rashid, 1910; Broomfield, 1968; Low, 1965; Mclane, R. John, 1965; Ghosha, et al., 1930).

Some important sections of Bangabandhu's 1972's constitution that reflected the dream of a golden Bangla has been mentioned here:

1) All power in the republic belong to the people of and their exercise on behalf of the people shall be affected only under and by the authority of this constitution (7.1)

2) Food, clothing, shelter, education and medical care include the provision of the basic necessities of life (15.a)

3) The right to work that is the right to guaranteed employment at a reasonable wage having regard to the quantity and quality of work (15.b)

4) The right to social securities (15-d)

5) Equality opportunity should be available to all citizen and remove social and economic inequality between man and woman (19-1,2)

6) Establishing a uniform mass oriented and universal education system and removing illiteracy within such time as may be determined by law (17-a, c)

7) To bring about a radical transformation in the rural areas through the promotion of an agricultural revolution (16)

8) All citizens are equal before law and entitled to equal protection of law.

9) Woman shall have equal rights with men in all spheres of the state and of public life (28-2)

10) The state shall not discriminate against any citizen on grounds only of religion, race, caste, sex or place of birth (28-1)
11) Every person in the service of the republic has a duty to strive at all times to serve the people (212).

The constitution of 1972 proves that Bangabandhu drew a progressive master plan of economic society and secular state to reform the war-torn Bangladesh (Melane, 1972; Mujeeb, 1967).

\section{Bangabandhu's Rehabilitation Program}

Bangabandhu government's new journey of reformation of independent Bangladesh started with a big responsibility of rehabilitating about 1 crore asylum seeker and rebuilding 43 lac houses devastated in the war (Rahman, Dr. Md. Mahbubar, 2005). Despite getting abundant amount of relief from foreign countries Bangabandhu' s government had to restructure Red Cross Society from national to root level since government's administrative infrastructure was almost collapsed. Moreover, different 5 and 10-member committees were formed based on the size and population of the villages to properly distribute the reliefs (Islam $e t$ al., 1991 \& Ahmed, 1994). Thus, the relief was distributed across the country through the union, Police station and district level committees. In a newspaper published on $4^{\text {th }}$ March, 1973 it is claimed that the government had rebuilt 9 lac houses and spent 72 crore and 70 lac Takas in overall rehabilitation program in the country (Rashid, 2001 \& Sobhan, Rehman, 1979).

\section{Bangabandhu's Nationalizing Program in The Eco- nomic Development}

In the first anniversary of independence Bangabandhu nationalized the country's jute, cloth, bank and insurance industries by law. Moreover, Bangabandhu for feited 85 percent of Pakistani's owned industries and occupied those assets as government property (Faaland et al., 1977 \& Muhit, Abul Mal Abdul, 1996). Under the act of nationalization government brought 67 jute mills, 64 cotton mills and 15 sugar mills under state property. Thus, foreign business worth about taka15 crore were nationalized at that time (Rahman et al., 2012; Sultana and Amin, 2020).

\section{Bangabandhu's Agricultural Reformation}

In post war Bangladesh almost 85 percent of its population was dependent on agriculture for their livelihood. More than half of the total national income was agriculture dependent. Bangabandhu called on a green 
revolution forwarding the slogan "Krishak bachle desh bachbe (The country will survive if the farmers survive)". Government rehabilitated approximate 12 lac family of farmers skillfully. Bangabandhu's mentionable initiatives in the field of agriculture are as follows:

1) Besides allocating money for building houses Bangabandhu distributed agricultural equipment and machineries, pesticides and fertilizer at almost free of cost.

2) Bangabandhu waived all the outstanding of land tax and withdrew land tax up to 15 big has of land size.

3) He determined land ownership ceiling of maximum 100 big has per family.

4) By the end of 1972 Bangabandhu arranged to set up 40000 low lift pump, 2900 deep tube well and 3000 tube well across the country (Bangabandhu's Speech, 26 March 1971 \& Rashid, Dr. Harun-or., 1988, 2001)

5) Bangabandhu also set up prices for paddy, jute, tobacco and sugarcane and other necessary agricultural products to ensure fair prices of such products.

6) Bangabandhu succeeded to start the Ganga-Kopotakkho Irrigation Project at full fledge within august, 1973.

7) Bangabandhu sent scientist Abbas to delhi on $21^{\text {st }}$ September, 1972 to discuss about Farakka barrage and managed to bring promise of 54 thousand quesec liter of water in the river Padma in dry season (Hasan, Mababub, 1988).

\section{Bangabandhu's Educational Reformation}

Bangabandhu gave his special focus in the expansion and promotion of education to develop human resources in the war-torn country. Within 6 months of his takeover Bangabandhu appointed "Bangladesh Education Commission" on $26^{\text {th }}$ July, 1972 under the leadership of distinguish scientist Dr. Kudrat E Khoda. Bangabandhu's undertook some appreciable initiatives in the educational reformation long before the submission of commission's report, like -

1) Waiving all dues of the students for the period of March, 1971 to December, 1971.

2) Paid war time due salary of 9 months for all teachers.

UniversePG I www.universepg.com
Distributed Books at free for the learners of up to class five and declared free learning in the schools for the students of up to class eight (Government Proceeding, 14 January, 1972).

1) Bangabandhu nationalized all the primary educational institution, consequently, jobs of all 1 lac 65 thousand primary teachers turned into public services.

2) Bangabandhu rebuilt 900 college building and 400 high school building destroyed in war time.

3) Another important initiative of Bangabandhu was that he gave Autonomy to all the public universities through establishing Public University Act 1973 in Parliament (Rahman, 2016).

\section{Bangabandhu's Economic Reformation}

Bangabandhu inherited a country which had no economic potential. To mobilize the economy of the war torn Bangladesh Bangabandhu initiated some revolutionary steps (Islam, 2011). At the very beginning Bangabandhu nationalized all the prime industries, like Banking, insurance and $80 \%$ of total foreign trade. Bangabandhu formed a planning commission and implemented $1^{\text {st }} 5$ yearly economic plan started from $1^{\text {st }}$ July, 1973. In the first five yearly plans besides country's reformation topics like economic indiscrimination, people friendly, progressive and developed Bangladesh were the key focus points (Constitution of Bangladesh, 16 December, 1972). Some Important direction of the first five yearly plans has been mentioned here: The first objective of planning would be reducing unemployment to the country.

In this purpose work opportunity and equity-based distribution would be ensured through regulating effective policy regarding commodity price (Mamoon et al., 2011; Imam, 2013).

1) Ensure reformation and increase productivity in every sector of the economy, especially the agriculture and industry sector.

2) To increase the economic growth rate to $5.5 \%$ from $3 \%$.

3) To increase productivity of all necessary commodity and keep the price affordable and stable for the poor class population of the country.

4) Setting resource distribution policy along with redistributable economic policy related strategy 
in such a way so that the income growth rate of the poor class people surpasses that of the overall population.

5) Reducing the dependency on foreign aid from $62 \%$ to $27 \%$ within the year 1971 - 1978 (Huq, Obaidul, 1973).

6) Ensure the institutional and technological transformation of agriculture and achieve self-sufficiency in food production.

Increase human productivity and capability through increased allotment in different human resource development index like education, health, rural housing, water and sanitation etc (Qudrat-E-Khuda Education Commission, 1973). But this is very much unfortunate for the nation that at the end of $2^{\text {nd }}$ years of implementation of this five yearly plan Bangabandhu along with his all-family members were brutally assassinated by a group of international conspirators on $15^{\text {th }}$ august, 1975 (Khaleduzzaman, 2020). While commenting on the comparative analysis of our country's economic scenario if Bangabandhu were alive Professor Abul Barakat said "The socio-economic class structure of Bangabandhu-less Bangladesh is $-2.7 \%$ people that is 44 lac people are in the rich class and $1 \%$ are highly rich, $31.3 \%$ are middle class (5 crore 1 lac) and $65.9 \%$ people are multilevel poor - who are about 10 crore and 55 lacs in number (Mamoon et al., 2013). The poor and rich discrimination is very much apparent in the Bangabandhu less Bangladesh. But if Bangabandhu were alive and his development philosophy were implemented then the socio-economic class structure of today's Bangladesh would have been like - the population of rich class would be reduced to $0.07 \%$ from exiting $2.7 \%$, the size of multilevel poor class would be reduced to $0.7 \%$ from existing $65.9 \%$. On the contrary the size of middle-class population would be reduced to 99.3\% from existing 31.3\% (Barakat, 2020).

To boost up the economy of the war-torn Bangladesh Bangabandhu initiated the following steps:

1) Bangabandhu formulated the first five yearly economic plan and set target of reducing foreign aid dependency from $62 \%$ to $27 \%$ within 1977 78 fiscal year.

2) Bangabandhu formed four economically important corporation like Bangladesh Jute Corpo- ration, Bangladesh Sugar corporation, Bangladesh Textile Corporation and Bangladesh Gas and Oil Corporation (Mamoon et al., 2013).

3) Bangabandhu established Bangladesh Industrial credit institution and Bangladesh Bank and open 1050 new branches of different banks across the country.

4) He instituted Bangladesh Krishi Bank and established 355 branches of this bank.

5) Bangabandhu introduced new currency for the independent Bangladesh.

6) Bangabandhu gave special importance in integrated Rural Development Programs (IRPD) with a view to rural development and established academy for rural development in Bogura.

7) Moreover, Bangabandhu started the primary stage of Ghorashal Fertilizer, Ashugonj complex and established many other new industries and reopened many closed industries to take forward the country toward a robust and growing economy (Huq, 1996).

\section{Communication and Transportation}

The road and rail communication system of the country were completely destroyed during the liberation war period. About 274 small and large bridges, 300 Rail Bridge were destroyed in the war. Hundreds of buses of public and private transport were also destroyed in the war Bangabandhu reconstructed almost all the bridges and culverts destroyed in the war within the year 1974 and he also constructed 97 new rail bridges across the country. He also reopened the destroyed rail bridges. The plan of building bridge over the river Jamuna was a revolutionary effort of Bangabandhu. In this regard he formed a commission, who submitted the Jamuna Bridge feasibility study report on $4^{\text {th }}$ November, 1974. Air Flight in the domestic route like Dhaka -Chittagong, Dhaka Sylhet, Dhaka - Jeshore, Dhaka- Cumilla were introduced during his period.

The Construction work of Kurmitola International Airport (present Hazrat Shahjalal International Airport) was started during his period (Bangladesh Private Aviation and Development Authority Report, 2019). Bangladesh Shipping Corporation was also formed by the order of Bangabandhu which added 14 ocean going ship within December, 1974. 


\section{Electricity Generation}

To develop the infrastructure of electric power supply Bangabandhu imported 5000 electric pole and set up 15 $\mathrm{km}$ length of electric line within December 1972. He also increased the electricity generation capacity from 200 megawatt to 500 megawatt. A master plan of expanding the Polli Bidyut program was also prepared during his period. Bangabandhu's government also managed to active 55000 telephone line within December 1974. Moreover, he also set up geo-satellite in Chittagong hill tract (Bangladesh Private Aviation and Development Authority Report, 2019).

\section{Measures in Women Welfare}

Bangabandhu established women rehabilitation board in 1972 for the welfare of poor women and created women rehabilitation welfare foundation in 1974 expanding the welfare board activities. He also managed $10 \%$ quota for women in the job sector (Mamoon et al., 2019).

\section{Bangabandhu's Initiative in Defense Sector}

Despite the financial limitation of the government Bangabandhu's effort in strengthening the defense system of the country was praise worthy. He ordered a decree to form BDR (Bangladesh Rifles) on $6^{\text {th }}$ March, 1972. In another ordinance he ordered to form padatic force (Bangladesh Army), Navy and Air force on $8^{\text {th }}$ April, 1972. On 11 March 1974 Bangabandhu established the first Military Academy in Cumilla (Mamun, 1996), Bangabandhu collected small and heavy arms for military force from then Yugoslavia. He also imported mig-aircraft, helicopter and cargo airbus from Soviet Union and purchased helicopter for Air force from UK (Khan, 2009).

He also collected military tank from Egypt. Bangabandhu sent the military officers abroad for developed training. Moreover, he formed a paramilitary force to keep the country's internal law and order situations under control (Chouddury et al., 1998).

\section{Contribution in health care}

To ensure healthcare as a basic human rights Bangabandhu initiated the establishment of health care center at thana (Police Station) level and sequentially established 31 bed hospital at 365 thanas (Police Station), established new medical college and post graduate medical institute around the country (Sen, 1985).

UniversePG I www.universepg.com

\section{Bangabandhu's Foreign Policy}

To recover from the war-torn condition with logical reason Bangabandhu government's foreign policy was basically a foreign economic policy. The source of financial help was very limited in the after-war period of 1972 - 1975. Mr. Abdus Samad and Dr. Kamal Hossain acted as the foreign minister of the country. But Bangabandhu was the main determinant and decision maker in foreign policy related issues. On $15^{\text {th }}$ January, 1972 Bangabandhu said "Friendship with all, enmity with none" that means a non-alliance policy was the fundamental principle of Bangabandhu's foreign policy. The future direction of Bangabandhu's foreign policies was very much clear in his words- "We want to build Bangladesh as the Switzerland of South Asia" (18). Bangabandhu's historical speech delivered in Bangla in UN's general assembly on $25^{\text {th }}$ September in 1974 indicated the fundamental characteristics of Bangabandhu's foreign policy (Abdul, 1987). Some mentionable achievement of Bangabandhu's foreign policy has been mentioned as follows:

1) Bangabandhu sent the Indian Military Force successfully back to their land just within 35 days of his power.

2) USA recognized Bangladesh as an independent country on $4^{\text {th }}$ April, 1972 just because of Bangabandhu's diplomatic initiatives.

3) Bangabandhu government got membership of International Monetary Fund (IMF) on $10^{\text {th }}$ May, 1972.

4) Bangladesh Achieved UN membership on $17^{\text {th }}$ September, 1974.

5) Bangabandhu's diplomatic intelligence enabled Bangabandhu to achieve membership of 14 international organization including commonwealth and OIC (Ahmed, 1984).

\section{CONCLUSION:}

After the nine months long liberation war Bangladesh was reduced into rubble. The Pakistani invaders destroyed almost all the communication systems and seaports of the country. They destroyed schools, colleges, universities, factories, houses, food ware-houses and markets. The country's economy was in complete disarray. Foreign exchange reserves and food stocks were destroyed. After the war, a prolonged drought and a devastating cyclone pushed the country towards a 
famine. As a result, armed robbery, looting and snatching took place across the country. The law-and-order situation in the country was dire. Bangabandhu's government was working hard to recover the country gripped with so many hurdles and challenges. But some leftist pro-China secret organizations started promoting Bangladesh's liberation war as an unfinished revolution and Mujib's government as an illegitimate government imposed by Russia and India. Some of them denied the country's independence. They attacked about 3,000 political activists, including four members of the ruling party. They launched an undeclared war against the government. The government-backed National Socialist Party makes the country's political situation fragile. The party attracted a large number of students under the banner of scientific socialism. As a result, many militant organizations joined the party. Soon the political situation in the country became unstable. But the antiliberation forces of the country and foreign forces engaged in various conspiracies against the new state and the Mujib government but failed to prevent the rise of Bangladesh. Bangabandhu government remained in power for only three and a half years and was able to achieve significant success in building the war-torn Bangladesh. His initiatives in rebuilding communications, rehabilitation, repatriating Indian troops, drafting constitution, establishing parliamentary system, holding national elections, forming a defense force, banning all communal politics, ending the terrible famine, improving education and establishing good relations with different countries were very significant. So, at the end of the above discussion, it is clear that Bangabandhu's role in the formation of war-torn Bangladesh was undeniable and admirable.

\section{ACKNOWLEDGEMENT:}

We would like to thank Mr. Md. Shaon Akter for valuable comments, suggestions and help in the present research.

\section{CONFLICTS OF INTEREST:}

The author's declared there are no conflicts of interest to publish it.

\section{REFERENCE:}

1) Abdul Alim, (1987). Bangabandhu's State Thought and Development Thought, Dhaka, Books Service, pp. 29-33.
2) Ahmed, Emajuddin, (1984). Foreign Policy of Bangladesh: A Small State's Imperative, Dhaka, Somai Prokisoni, pp.81-92.

3) Ahmed. Moudud, (1990). Era of Sheikh Mujibur Rahman, Dhaka: University Press Limited. pp. 31-79.

4) Ahmed, Moudud, (1994), Bangladesh: Sheikh Mujibur Rahmanr Shasonamol, Dhaka, Somoi Prokashani, pp. 37-39.

5) Ali, Dr. Aziz (1982). Bangabandhu's Agricultural Reforms, 1972-75, Dhaka, Aligar, pp.140-167.

6) Bangabandhu's Bangladesh Television Speech, 26 March 1972; Rashid, Dr. Harun-or-(1988), 'The Muslim League in East Bengal: The 1954 Elections and after', Journal of the Asiatic Society of Bangladesh (Humanities), 33(1), pp. 130-140.

7) Barakat, Abul, (2020). 'Bangabandhu's Philosophy: Theory, Application and Elimination of Possibilities', Development of Rajshahi: Problems and Prospects of the Regional Seminar on the Seminar, Rajshahi, RUET Auditorium, pp. 31-32.

8) Bhatanagar, Yatinda. (1971).Mujib the Architect of Bangladesh: A Political Biography, Delhi: Indian school supply Department, p.89.

https://catalogue.nla.gov.au/Record/2615087

9) Broomfield, J.H.(1968), 'The Forgotten Majority: The Bengla Muslim and September 1918'; Low, D.A. ed., (1965), Soundings in Modern South Asian History, London, p.203

10) Faaland, Just and Parkinson, J. R. (1977). Bangladesh: The Test Case of Development, New Delhi, S. Chand \& Company Ltd., p.197.

11) Ghosha, Nityapriy \& Mukhopadhyay, Ashoke Kumar (1930), Partition Bengal 1905-1911 AD, Delhi, Shishu Sahitya Samsad Pvt. Ltd., pp.9599.

12) H.T. (2013). Bangladesh Sarker, 1972-75, Dhaka, Somai Prokisoni.pp.70-93.

13) Hasan, Mababub, (1988). "Politics in Bangladesh", Journal of the Asiatic Society of Bangladesh (Humanities), 33(1), pp.130-140.

14) Hassan, Zahir, (1994). The Separation of East Pakistan, Karachi: Oxford University Press, 76. https://www.amazon.com/Separation-East-Pakist an-Realization-Nationalism/dp/0195774922 
15) Huq, Obaidul, (1973). Bangabandhu Sheikh Mujib: A Leader with A Difference, Dhaka, $2^{\text {nd }}$ edition, pp.134-155.

16) Huq, Obaidul, (1996). Bangabandhu Sheikh Mujib: A Leader with A Difference, Dhaka: Asiatic Society, pp 99-103.

https://www.worldcat.org/title/bangabandhu-sheikh -mujib-a-leader-with-a-difference/oclc/34789863

17) Islam, Major Rafiqul, (1991). Genocide in Bangladesh: Harrowing Accounts of Some Eye-Witness and the Extracts from the Press, Dhaka, Upoma Prokashani, pp.130-141.

18) Islam, Shirajul, (2011). Banglapedia, 13, Dhaka, Asiatic Society of Bangladesh, pp.170-171.

19) Khaleduzzaman, Md. (2020). 'Qudrat-E-Khuda Education Commission and Its Uses in Bangladesh', IOSR Journal of Research \& Method in Education (IOSR-JRME), 10(4), pp 27-36. https://doi.org/10.9790/7388-1004072736

20) Khan, Shamsuzzaman, (2009). Bangabandhu's State Thought and Present Bangladesh, Dhaka, Vijay Prakashani, pp.11-13.

21) Mamoon, Muntassir \& Rahman, Md. Mahbubar, (2019). History of the Emergence of Independent Bangladesh, Dhaka: Suborno, p.253.

22) Mamun, Abdullah Al, (1996). Bangabandhu Sheikh Mujibur: Contribution to the service of Islam and Humanity, Dhaka: Shobha Publications, p.39.

https://en.wikipedia.org/wiki/Sheikh_Mujibur_Rah man

23) Maniruzzaman, Talukder, (1975). 'Bangladesh: An Unfinished Revolution', the Journal of Asian Studies, 34(4), p. 4.

https://www.jstor.org/stable/2054506

24) Maniruzzaman, Talukder, (1982). Group Interests and Political Changes: Studies of Pakistan and Bangladesh, New Delhi, p. 24.

https://catalogue.nla.gov.au/Record/571872

25) Maniruzzaman, Talukder, (1975). "Bangladesh: A Unfinished Revolution", The Journal of Asian Studies, 34(4), pp.22-27.

26) Manzur, Murshed, (1979). Mukti Bahini-Its Organization, Grouth and Development, The Rajshahi University Studies, 9(10), pp.89-99.

27) Mclane, R. John, (1965). 'The Decision to Partition Bengal in 1905', The Indian Economic
\& Social History Review, 2(3), pp.221-237. https://doi.org/10.1177/001946466400200302

28) Melane, J. R. (1972). Partition of Bangal 1905: A Political Analysis', Chowdhury, Shirajul Islam (ed.), History of Bangladesh, 1904-1971, 11, Dhaka: Asiatic Society of Bangladesh, pp.172177.

29) Morris-Jones, W. H. (1972). "Pakistan Post-Mortem and the Roots of Bangladesh", Political Quarterly, 18, pp.187-200.

30) Muhit, Abul Mal Abdul, (1996). American Response to Bangladesh Liberation War, Dhaka, University Press.pp.40-51. https://www.amazon.com/Bangladesh-Test-Develo pment-Just-Faaland/dp/0903983419

31) Mujeeb, M. (1967). The Indian Muslim,London, Oxford University Press, pp.29-34.

32) Rahman, Dr. Md. Mahbubar, (2005). History of the Bangladesh, 1947-71, Dhaka: Somoy Prakashan, pp. 243-247.

33) Rahman, Dr. Md. Mahbubar, (2005). History of the Bangladesh, 1947-71, Dhaka, Somai Prokasiny, pp. 310-311.

34) Rahman, Md. Mahbubur, (2016). Bangabandhur shasonamol, 1972-75, Dhaka, Bangladesh Awami League, pp. 257-258.

35) Rahman, Sheikh Mujibur, (2012). Asomapto Aattajeboni, Dhaka, University Press Ltd., p.34.

36) Rahman, Mofizur, (1995). 'Speeches at Dhaka Race Course and Gettysburg', The Financial Express, Dhaka, p.9.

37) Rashid, Dr. Harun-or, (1991). 'The Dhaka Nawab Family in Bengal Politics,' Sharif Uddin Ahmed (ed.), Dhaka: Past and Present Future, Dhaka, p.141.

38) Rashid, Dr. Harun-or, (2001), Bangladesh: Politics Governance and Constitutional Development 1757-2000, Dhaka: New Age, pp.192-295.

39) Report published by Bangladesh Private Aviation and Development Authority' (2019). A decade of development of Bangladesh 2009-2018,Institute of Conflict Law \& Development Studies (ICLDS), Dhaka, Ministry of Information, p.27.

40) Safar A. Akand, (1970). 'East Pakistan and Politics of Regionalism,' Unpublished Ph.D Thesis, University of Denver, Denver, USA.

https://openresearch-repository.anu.edu.au1989.pdf 
41) Salik, Siddiq, (1978). Witness to Surrender, $O x$ ford: Oxford University Press, pp. 122-123,139180.

https://www.amazon.com/Witness-Surrender-Siddi q-Salik/dp/0195777611

42) Sen, Rangalal, (1985). Political Elites in Bangladesh, Dhaka: Aligor, pp.13-19.

43) Sobhan, Rehman, (1979). Politics, Food and Famine in Bangladesh,' The Journal of Economic and Political Weekly, 2(4), pp.165-173.

44) Sultana J., and Amin MA. (2020). Historic 7th March Speech of Bangabandhu: Democracy and
Civility in Leadership, Asian J. Soc. Sci. Leg. Stud., 2(2), 33-40.

https://doi.org/10.34104/ajssls.020.033040

\section{Government Proceeding}

Proceeding Bangladesh Government 14 January, 1972.

Constitution of the People's Republic of Bangladesh 16

December, 1972.

Newspaper

Newsweek, 5 April, 1971.

Citation: Tawhid MH., and Karim DMR. (2021). Bangabandhu Sheikh Mujibur Rahman in the formation of war-torn Bangladesh, Asian J. Soc. Sci. Leg. Stud., 3(6), 237-246.

https://doi.org/10.34104/ajssls.021.02370246 @) () 